\title{
PENGARUH MODEL PEMBELAJARAN TWO STAY TWO STRAY TERHADAP HASIL BELAJAR SEJARAH DI SMA NEGERI 7 MEDAN
}

\author{
Marcho Alex Samuel Silitonga \\ Alumni Jurusan Pendidikan Sejarah, Universitas Negeri Medan, Indonesia \\ Email: marchoalexsamuel@gmail.com
}

\begin{abstract}
This study aims to determine the effect of the application of the Two Stay Two Stray learning model (TSTS) to the history of student learning outcomes at SMA Negeri 7 Medan. The research method used is quasi-experimental. The study population was students of class X IPS with a sample of 65 students consisting of 34 students of class X IPS 2 as an experimental class and 31 students of class X IPS 1 as a control class. Data collection techniques using observation and tests. The data obtained were analyzed using the t-test. The observation results showed that $91 \%$ of the experimental class students who took part in learning with the TSTS model got very good average scores. The average post-test value of the experimental class was 80.3, while the average value of the post-test of the control class that followed the learning with the conventional model was 63.70. T-test results for the post-test scores were obtained $t_{\text {count }}$ $>t_{\text {table }}(7,004>1,670)$. These results indicate that the TSTS learning model has a great influence in improving the history of student learning outcomes in class XI IPS 2 SMA Negeri 7 Medan.
\end{abstract}

Keywords: Learning Model, Learning Outcomes, TSTS

\begin{abstract}
Abstrak
Penelitian ini bertujuan untuk mengetahui pengaruh penerapan model pembelajaran Two Stay Two Stray (TSTS) terhadap hasil belajar sejarah siswa di SMA Negeri 7 Medan. Metode penelitian yang digunakan adalah eksperimen semu. Populasi penelitian adalah siswa kelas X IPS dengan sampel penelitian 65 siswa yang terdiri dari 34 orang siswa kelas X IPS 2 sebagai kelas eksperimen dan 31 orang siswa kelas X IPS 1 sebagai kelas kontrol. Teknik pengumpulan data menggunakan observasi dan tes. Data yang diperoleh dianalisis dengan menggunakan uji-t. Hasil observasi menunjukkan bahwa 91\% siswa kelas eksperimen yang mengikuti pembelajaran dengan model TSTS memperoleh nilai rata-rata yang sangat baik. Nilai rata-rata post-test kelas eksperimen sebesar 80,3 , sedangkan nilai rata-rata post-test kelas kontrol yang mengikuti pembelajaran dengan model konvensional sebesar 63,70. Hasil uji-t terhadap nilai post-test diperoleh $t_{\text {hitung }}>t_{\text {tabel }}(7,004>1,670)$. Hasil ini menunjukkan bahwa model pembelajaran TSTS memiliki pengaruh yang besar dalam meningkatkan hasil belajar sejarah siswa kelas XI IPS 2 SMA Negeri 7 Medan.
\end{abstract}

Kata Kunci: Model Pembelajaran, Hasil Belajar, TSTS 


\section{PENDAHULUAN}

Sejarah merupakan salah satu mata pelajaran yang diajarkan di lembaga pendidikan formal, mulai dari jenjang pendidikan Sekolah Dasar (SD) hingga Sekolah Menengah Atas (SMA). Di SMA Negeri 7 Medan, mata pelajaran sejarah yang diajarkan di kelas XI terdiri dari dua bagian: a) sejarah wajib, dan b) sejarah peminatan. Keduanya dipelajari oleh siswa kelas IPS (Ilmu Pengetahuan Sosial), sedangkan siswa kelas IPA (Ilmu Pengetahuan Alam) hanya mempelajari sejarah wajib. Mata pelajaran sejarah yang diajarkan kepada siswa bertujuan untuk menumbuhkan kesadaran dalam diri siswa bahwa mereka bagian dari bangsa Indonesia yang memiliki rasa bangga dan cinta tanah air, serta melahirkan empati dan perilaku toleransi yang dapat diimplementasikan dalam berbagai bidang kehidupan.

Berdasarkan hasil observasi di kelas XI IPS SMA Negeri 7 Medan diketahui bahwa kurikulum yang digunakan oleh guru sejarah di sekolah tersebut adalah kurikulum 2013 revisi. Namun, proses pembelajaran di kelas masih terkesan monoton karena guru terlihat lebih aktif dibandingkan dengan siswa. Hal ini terjadi karena guru sejarah hanya menggunakan metode teacher centered dalam proses pembelajaran. Metode tersebut membuat proses pembelajaran di kelas terkesan menbosankan karena siswa cenderung pasif. Siswa hanya menjadi pendengar dan jarang sekali mengutarakan pendapat, bertanya atau menjawab pertanyaan. Proses pembelajaran seperti ini membuat siswa cepat merasa bosan dan jenuh. Bahkan siswa terlihat kurang memperhatikan penjelasan guru. Mereka justru lebih sering berbicara dengan teman sebangkunya.

Model pembelajaran konvensional yang digunakan guru sejarah di kelas XI IPS SMA Negeri 7 Medan ternyata membuat hasil belajar siswa relatif rendah. Hal ini terlihat dari hasil ujian mata pelajaran sejarah yang diperoleh siswa kelas XI IPS 1 pada semester ganjil Tahun Ajaran 2018/2019. Dari 31 siswa di kelas XI IPS
1 hanya 10 siswa yang memperoleh nilai antara 75-95, sedangkan 21 siswa mendapat nilai di bawah KKM (Kriteria Ketuntasan Minimal). Hasil itu menunjukkan bahwa tujuan pembelajaran sejarah di SMA Negeri 7 Medan masih belum tercapai.

Rendahnya hasil belajar sejarah siswa di kelas XI IPS SMA Negeri 7 Medan tentu saja menuntut guru untuk meningkatkan kualitas pembelajaran di kelas agar tujuan pembelajaran sejarah dapat tercapai dengan maksimal. Kualitas pembelajaran dapat dicapai secara maksimal dengan cara meningkatkan keterlibatan peserta didik dalam proses belajar mengajar di kelas. Ketika siswa terlibat aktif dalam proses pembelajaran, maka hasil belajar mereka akan ikut mengalami peningkatan (Hamalik, 2015). Oleh karena itulah guru harus mampu menggunakan model pembelajaran yang dapat memungkinkan siswa lebih aktif dalam mengikuti proses belajar mengajar di kelas. Menurut Subratha (2007), model pembelajaran yang baik adalah model pembelajaran yang berfokus pada pengembangan pemahaman konsep, pengembangan intraksi kelompok dan kerjasama, serta latihan memecahkan masalah. Model pembelajaran yang memenuhi kriteria tersebut adalah model pengajaran kooperatif.

Menurut Pradhana dan Pramukantoro (2013: 662), pembelajaran kooperatif adalah salah satu bentuk pembelajaran yang berdasarkan faham konstruktif. Pembelajaran kooperatif merujuk pada berbagai macam model pengajaran di mana peserta didik bekerja dalam kelompok-kelompok kecil untuk saling membantu satu sama lain dalam memperlajari materi pelajaran, memecahkan masalah dan menyelesaikan tugas-tugas terstruktur melalui diskusi (Dewijayanti, dkk., 2014:253). Penerapan model pembelajaran ini dapat meningkatkan motivasi belajar siswa. Siswa dapat berinteraksi secara positif dengan teman sekelasnya, menerima teman sekelas yang lemah dalam akademik dan meningkatkan rasa harga diri. Selain itu, pembelajaran kooperatif dapat pula memotivasi 
siswa untuk berpikir kritis sehingga pemahaman mereka terhadap materi pelajaran lebih mendalam. Dengan begitu, prestasi siswa akan meningkat (Wardhani, dkk., 2012).

Salah satu tipe pembelajaran kooperatif adalah Two Stay Two Stray (TSTS). Menurut (Dewijayanti, dkk., 2014: 253), model pembelajaran TSTS adalah salah satu tehnik belajar kooperatif yang memberikan kesempatan pada siswa untuk saling berbagi informasi tentang materi pelajaran yang mereka ketahui. Model pembelajaran TSTS juga membagi siswa dalam kelompok sehingga dapat membantu siswa agar lebih aktif dalam berdiskusi, bertanya dan menyampaikan pendapat. Dengan kata lain, belajar dengan kelompok diharapkan dapat meningkatkan aktivitas dan hasil belajar siswa.

Lebih lanjut (Dewijayanti, dkk., 2014: 253) menjelaskan bahwa TSTS merupakan model pembelajaran yang dapat melatih siswa berfikir kritis, kreatif dan efektif serta saling membantu memecahkan masalah dan saling mendorong untuk saling berprestasi dalam kelompoknya dan kelompok lain. Hal ini dikarenakan model pembelajaran TSTS memungkinkan satu kelompok untuk saling berbagi informasi dengan kelompok lain dan membandingkan hasil kerja mereka sehingga proses pembelajaran dapat berjalan efektif. Setiap siswa bebas untuk mengemukakan pendapat, ide, gagasan dan kritik sehingga suatu konsep yang dibentuk akan lebih bermakna. Pada saat berdiskusi, siswa dituntut untuk benar-benar bekerjasama dalam hal saling bertukar pendapat terhadap hasil diskusi kelompok. Proses pembelajaran ini mendorong siswa untuk ikut serta dalam menentukan tujuan pembelajaran, cara belajar dan mengevaluasi hasil belajarnya sendiri (Zulkarnain \& Rachman, 2016: 32-33).

Model pembelajaran TSTS juga menuntut siswa untuk bertanggung jawab terhadap proses belajar sehingga dapat menjadikan siswa lebih menyedari tentang konsep yang dipelajari selama proses pembelajaran. Siswa mengkonstruksi sendiri konsep belajar dan solusi terhadap permasalahan yang mereka hadapi. Oleh karena itu, siswa tidak seharusnya bergantung pada guru untuk belajar, namun siswa seharusnya mandiri dalam belajar sepanjang hidupnya (Dewijayanti, dkk., 2014: 253). Peranan guru dalam model pembelajaran TSTS hanya sebagai fasilitator dan mediator yang kreatif karena siswa dituntun belajar secara kelompok dan tanggung jawab tentang pengetahuan yang diperolehnya.

Dewijayanti, dkk. (2014: 253) menjelaskan bahwa langkah pembelajaran TSTS meliputi kerja sama dalam kelompok berempat, berbagi informasi antarkelompok, mendiskusikan ulang hasil temuan dari kelompok lain bersama kelompok masing-masing, selanjutnya mempresentasikan hasil diskusi. Dalam tiap kelompok terdapat dua siswa sebagai tamu dan dua siswa sebagai tuan rumah. Tamu bertugas mencari informasi dari kelompok lain, sedangkan tuan rumah bertugas menyampaikan informasi kepada kelompok lain.

Berdasarkan uraian di atas, model pembelajaran TSTS kiranya dapat menjadi alternatif bagi guru-guru sejarah. Pertanyaannya kemudian, apakah model pembelajaran ini dapat menjadi solusi bagi permasalahan dalam pembelajaran sejarah di kelas XI SMA Negeri 7 Medan? Untuk menjawabnya, penelitian ini akan mengkaji sejauhmana pengaruh model pembelajaran TSTS terhadap hasil belajar siswa di kelas XI IPS SMA Negeri 7 Medan.

\section{METODE PENELITIAN}

Kajian ini menggunakan metode penelitian eksperimen semu (quasi experiment) dengan desin penelitian nonequivalent control group design (desain dengan kelompok kontrol tak setara). Tujuannya untuk membandingkan hasil belajar sejarah siswa di dua kelas, yaitu kelas eksperimen yang diberikan model pembelajaran TSTS dengan kelas kontrol dengan model pembelajaran konvensional. Penelitian ini dilakukan di SMA Negeri 7 Medan, Sumatera Utara, pada semester genap Tahun Ajaran 2018/2019. 
Populasi penelitian adalah siswa kelas XI IPS yang terdiri dari tiga kelas. Pengambilan sampel dilakukan dengan cara random sampling untuk mengambil 2 kelas dari populasi. Hasilnya, sampel untuk kelas eksperimen adalah kelas XI IPS 2 dengan jumlah siswa sebanyak 34 orang, sedangkan kelas kontrol jatuh pada kelas XI IPS 1 dengan jumlah siswa 31 orang.

Teknik pengumpulan data menggunakan observasi dan tes hasil belajar. Tes disusun berdasarkan kurikulum dan tujuan pembelajaran. Tes hasil belajar diberikan kepada kelas eksperimen dan kelas kontrol sebanyak dua kali, yakni pre-test dan post-test. Data dari tes hasil belajar kemudian diuji normalitas dan homogenitasnya. Uji normalitas dilakukan untuk menyajikan bahwa sampel benar-benar berasal dari populasi yang berdistribusi normal, sedangkan uji homogenitas dilakukan untuk menyajikan bahwa sampel benar-benar homogen. Untuk menguji homogenitas varians data sampel digunakan uji Fisher (uji F). Sementara itu, uji hipotesis terhadap instrumen hasil belajar menggunakan uji t dua pihak dan uji t satu pihak. Uji $t$ dua pihak digunakan untuk mengetahui kemampuan awal siswa, sedangkan uji t satu pihak digunakan untuk mengetahui pengaruh model pembelajaran tipe TSTS terhadap hasil belajar siswa.

\section{HASIL DAN PEMBAHASAN}

Aspek yang diamati dalam penelitian aktivitas siswa ini sesuai dengan langkah-langkah model pembelajaran kooperatif tipe TSTS dalam Rencana Proses Pembelajaran (RPP). Data hasil pengamatan terhadap aktivitas belajar siswa selama kegiatan belajar mengajar di kelas eksperimen disajikan dalam tabel 1 .

Data tabel 1 menunjukkan bahwa aktivitas siswa secara keseluruhan sudah tergolong aktif dalam mengikuti proses pembelajaran. Hal ini ditandai dengan adanya aktifitas siswa dalam setiap langkah-langkah pembelajaran dan nilai rata-ratanya mencapai $91 \%$.

Sementara itu, hasil observasi terhadap proses pembelajaran di kelas kontrol menunjukkan bahwa kegiatan pertama yang dilakukan oleh guru sejarah adalah mengucapkan salam kepada siswa, kemudian guru mengabsen siswa dengan cara menanyakan kepada sekretaris kelas tentang nama-nama siswa yang tidak hadir. Setelah itu, guru menyampaikan kepada siswa mengenai materi pelajaran yang akan dipelajari. Pada kegiatan inti, guru menerangkan materi pelajaran secara singkat kepada siswa, serta meminta siswa untuk membaca dan memehami garis besar materi pelajaran dari buku paket dan LKS (Lembar Kerja Siswa).

Tabel 1. Aktivitas Siswa pada Model Pembelajaran TSTS

\begin{tabular}{|c|c|c|}
\hline No & Aspek yang Diamati & Skor \\
\hline 1 & $\begin{array}{l}\text { Pendahuluan } \\
\text { a. Siswa terlibat aktif, mendengar dan menanggapi pernyataan guru pada } \\
\text { kegiatan apresiasi. } \\
\text { b. Siswa memberikan pertanyaan dan menjawab pertanyaan guru pada } \\
\text { kegiatan motivasi. } \\
\text { c. Siswa mendengarkan langkah-langkah model pembelajaran TSTS. }\end{array}$ & $\begin{array}{l}4 \text { (Baik Sekali) } \\
3 \text { (Baik) } \\
4 \text { (Baik Sekali) }\end{array}$ \\
\hline 2 & $\begin{array}{l}\text { Kegiatan } \\
\text { a. Siswa duduk dalam kelompok diskusi. } \\
\text { b. Siswa mendapatkan permasalahan dari guru yang akan didiskusikan } \\
\text { antarkolompok melalui berbagai sumber belajar, seperti buku paket, } \\
\text { buku LKS maupun sumber lainnya. } \\
\text { c. Siswa menjalankan model pembelajaran TSTS dengan melakukan dua } \\
\text { siswa setiap kelompok untuk bertamu ke kelompok lainnya dengan } \\
\text { tujuan mencari informasi mengenai masalah yang telah didiskusikan ke }\end{array}$ & $\begin{array}{l}4 \text { (Baik Sekali) } \\
4 \text { (Baik Sekali) }\end{array}$ \\
\hline
\end{tabular}




\begin{tabular}{|l|l|c|}
\hline & $\begin{array}{l}\text { setiap kelompok lain, dan dua siswa lainnya untuk tetap di kelompoknya } \\
\text { dan menerima tamu dari kelompok lain untuk memberikan informasi } \\
\text { mengenai permasalahan yang telah didiskusikan oleh kelompoknya } \\
\text { masing-masing. }\end{array}$ & \\
d. $\begin{array}{l}\text { Setiap siswa yang menjadi kelompok tamu telah mendapat informasi } \\
\text { mengenai masalah yang telah didiskusikan oleh kelompok lain, maka } \\
\text { kelompok tamu dipersilahkan untuk kembali ke kelompok asalnya dan } \\
\text { siswa menyebarkan informasi yang telah didapat oleh kelompok tamu } \\
\text { kepada kelmpk masing-masing. }\end{array}$ & (Baik Sekali) \\
e. Setiap kelompok diberi kesempatan untuk mempresentasikan hasil \\
diskusinya ke depan kelas dan kelompok lain mencocokkan informasi \\
yang telah didapatkan dari kelompok yang akan melakukan presentasi di \\
depan kelas, dan mencatat setiap informasi ke dalam kertas jeruk atau \\
kertas karton yang telah disediakan.
\end{tabular}

Selanjutnya, guru meminta masing-masing siswa untuk meringkas materi pelajaran yang telah dipelajari ke dalam buku catatan. Sewaktu bel sekolah berbunyi yang menandakan jam pelajaran telah berkahir, guru memberikan instruksi kepada siswa untuk melanjutkan meringkas materi pelajaran di rumah dan mengumpulkannya pada pertemuan selanjutnya.

Sebelum dilakukan perlakuan khusus kepada kelas eksperimen dan kelas kontrol, seluruh siswa di kedua kelas tersebut diberikan pre-test. Data hasil pre-test siswa kelas eksperimen disajikan dalam tabel 2, sedangkan data hasil pre-test siswa kelas kontrol dapat dilihat pada tabel 3.

Tabel 2. Hasil Pre-Test Kelas Eksperimen

\begin{tabular}{|c|c|c|c|}
\hline Nilai & Frekuensi & Rata-Rata & $\begin{array}{l}\text { Standar } \\
\text { Deviasi }\end{array}$ \\
\hline $30-34$ & 3 & \multirow{7}{*}{49,85} & \multirow{7}{*}{9,25} \\
\hline $35-39$ & - & & \\
\hline $40-44$ & 4 & & \\
\hline $45-49$ & 6 & & \\
\hline $50-54$ & 5 & & \\
\hline $55-59$ & 7 & & \\
\hline $60-64$ & 9 & & \\
\hline \multicolumn{2}{|c|}{$\Sigma 34$} & & \\
\hline
\end{tabular}

Tabel 3. Hasil Pre-Test Kelas Kontrol

\begin{tabular}{|c|c|c|c|}
\hline Nilai & Frekuensi & Rata-Rata & $\begin{array}{l}\text { Standar } \\
\text { Deviasi }\end{array}$ \\
\hline $30-37$ & 10 & \multirow{7}{*}{46,61} & \multirow{7}{*}{12,47} \\
\hline $38-45$ & 5 & & \\
\hline $46-53$ & 7 & & \\
\hline $54-61$ & 5 & & \\
\hline $62-69$ & 2 & & \\
\hline $70-77$ & 2 & & \\
\hline $30-37$ & 10 & & \\
\hline \multicolumn{2}{|c|}{$\Sigma 31$} & & \\
\hline
\end{tabular}

Tabel 2 menunjukkan bahwa hasil pre-test kelas ekperimen dengan jumlah siswa 34 orang memiliki nilai rata rata sebesar 49,85 dengan standar deviasi 9,25, sedangkan tabel 3 menunjukkan hasil pre-test kelas kontrol dengan jumlah siswa 31 orang yang memiliki nilai ratarata 46,61 dengan standar deviasi 12,47.

Gambar 1 dan 2 memperlihatkan dengan lebih jelas hasil pre-test kelas eksperimen dan kelas kontrol. Setelah hasil pre-test diperoleh, penelitian ini dilanjutkan dengan memberikan perlakuan yang berbeda terhadap kedua kelas. Kelas eksperimen akan diberikan perlakuan menggunakan model pembelajaran TSTS, sedangkan kelas kontrol diberikan perlakuan dengan model pembelajaran konvensional. 


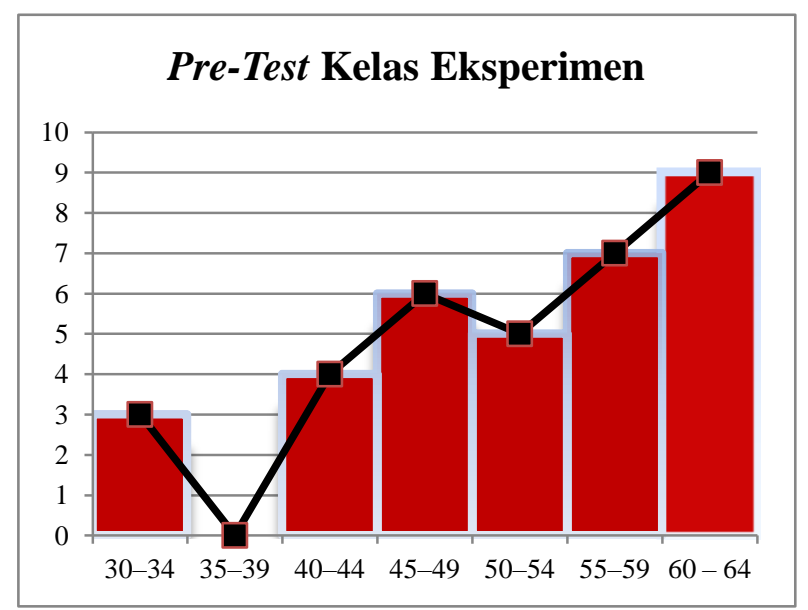

Gambar 1. Grafik Hasil Pre-Test Kelas Eksperimen

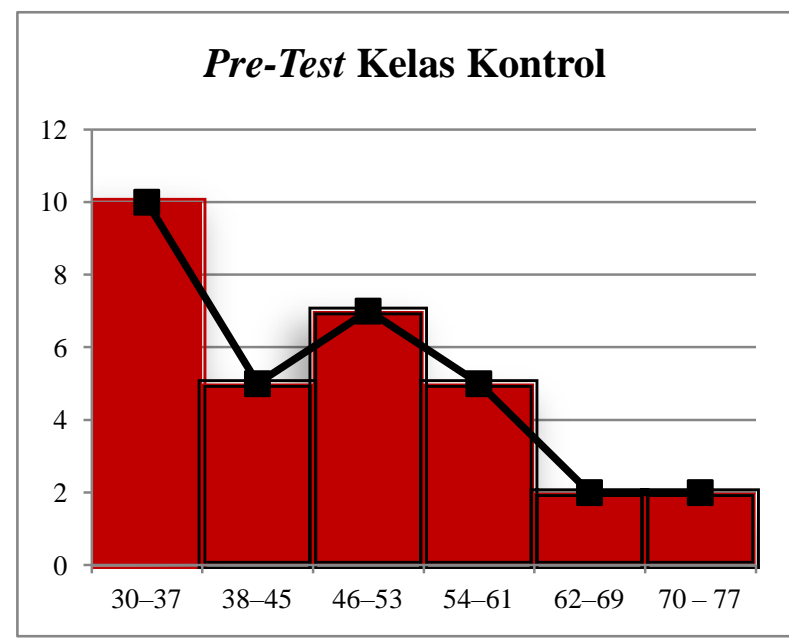

Gambar 2. Grafik Hasil Pre-Test Kelas Kontrol

Setelah kedua kelas diberi perlakuan yang berbeda, peneliti melakukan post-test terhadap kedua kelas. Data hasil post-test kelas eksperimen disajikan dalam tabel 4 , sedangkan data hasil post-test kelas kontrol dapat dilihat pada tabel 5.

Tabel 4 menunjukkan bahwa hasil posttest kelas ekperimen dengan jumlah siswa 34 orang memiliki nilai rata rata sebesar 80,3 dengan standar deviasi 8,7. Hal ini menunjukkan adanya peningkatan hasil belajar siswa kelas eksperimen. Dari sebelum diberikan perlakuan nilai rata-rata pre-test mereka hanya 58,08, setelah diberi perlakuan dengan model pem- belajaran TSTS nilai rata-rata post-test mereka meningkat mencapai 80,3. Perolehan nilai posttest siswa kelas eksperimen dapat dilihat lebih jelas pada gambar 3 .

Tabel 4. Hasil Post-Test Kelas Eksperimen

\begin{tabular}{|c|c|c|c|}
\hline Nilai & Frekuensi & Rata-Rata & $\begin{array}{c}\text { Standar } \\
\text { Deviasi }\end{array}$ \\
\cline { 1 - 2 } $55-61$ & 1 & & \\
\cline { 1 - 2 } $62-68$ & 2 & \multirow{3}{*}{80,3} & \multirow{2}{*}{8,7} \\
\hline $69-75$ & 8 & & \\
\cline { 1 - 2 } $76-82$ & 8 & & \\
\cline { 1 - 2 } $83-89$ & 9 & & \\
\hline $90-96$ & 6 & & \\
\hline \multicolumn{2}{|c|}{$\Sigma 34$} & &
\end{tabular}

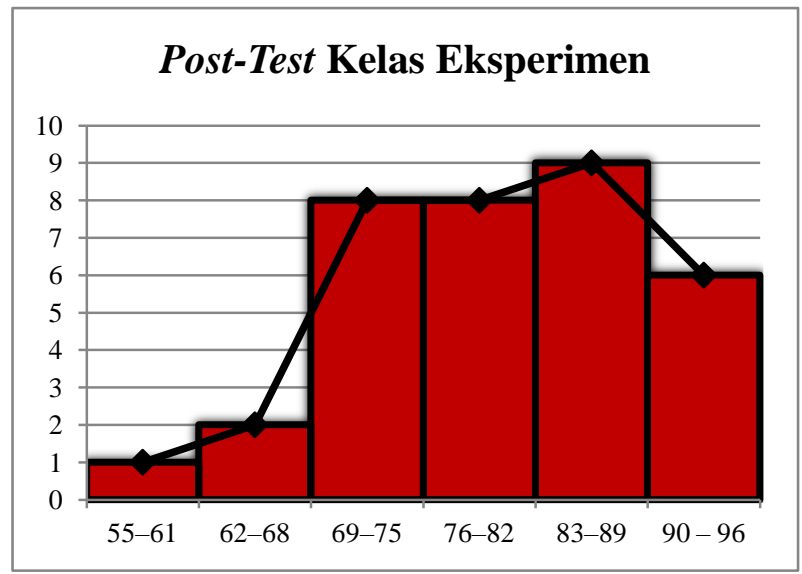

Gambar 3. Grafik Hasil Post-Test Kelas Eksperimen

Tabel 5. Hasil Post-Test Kelas Kontrol

\begin{tabular}{|c|c|c|c|}
\hline Nilai & Frekuensi & Rata-Rata & $\begin{array}{l}\text { Standar } \\
\text { Deviasi }\end{array}$ \\
\hline $45-50$ & 5 & \multirow{6}{*}{63,70} & \multirow{6}{*}{10,64} \\
\hline $51-56$ & 5 & & \\
\hline $57-62$ & 3 & & \\
\hline $63-68$ & 5 & & \\
\hline $69-75$ & 10 & & \\
\hline $76-81$ & 3 & & \\
\hline \multicolumn{2}{|c|}{$\Sigma 31$} & & \\
\hline
\end{tabular}

Tabel 5 menunjukkan hasil post-test kelas kontrol dengan jumlah siswa 31 orang yang memiliki nilai rata-rata 63,70 dengan standar 
deviasi 10,64. Hasil ini memperlihatkan nilai rata-rata siswa kelas kontrol sedikit mengalami peningkatan. Dari sebelum diberi perlakuan nilai rata-ratanya hanya 46,61 , setelah diberi materi pelajaran dengan model pembelajaran konvensional nilai rata-rata post-test mereka sebesar 63,70. Perolehan nilai post-test siswa kelas kontrol dapat dilihat lebih jelas pada gambar 4 .

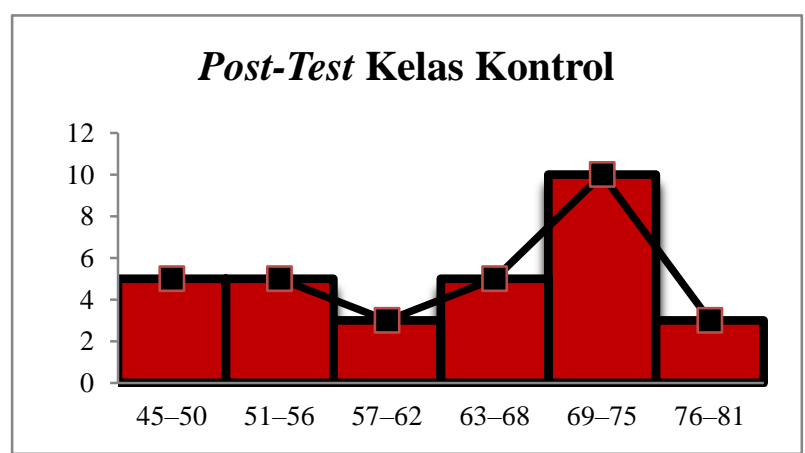

Gambar 4. Grafik Hasil Post-Test Kelas Kontrol

Data hasil pre-test dan post-test dari kelas eksperimen dan kelas kontrol kemudian diuji dengan menggunakan uji statistik parametrik yang memiliki beberapa persyaratan, yaitu uji normalitas, uji homogenitas dan uji kesamaan rata-rata. Uji normalitas dilakukan dengan menggunakan uji lillifors dengan kriteria pengu- jian $\mathrm{L}_{\text {hitung }}<\mathrm{L}_{\text {tabel }}$. Hasil uji normalitas disajikan dalam tabel 6 .

Tabel 6 menunjukkan bahwa hasil uji normalitas terhadap data pre-test dan post-test kelas ekperimen adalah berdistribusi normal, di mana hasil pre-test $\mathrm{L}_{\text {hitung }}<\mathrm{L}_{\text {tabel }}(0,1357<0,1519)$ dan hasil post-test $\mathrm{L}_{\text {hitung }}<\mathrm{L}_{\text {tabel }}(0,1181<$ 0,1519). Hasil uji normalitas terhadap data pretest dan post-test kelas kontrol juga berdistribusi normal, di mana hasil pre-test $\mathrm{L}_{\text {hitung }}<\mathrm{L}_{\text {tabel }}$ ( $0,1535<0,1593)$ dan hasil post-test $\mathrm{L}_{\text {hitung }}<$ $\mathrm{L}_{\text {tabel }}(0,1135<0,1593)$.

Setelah populasi dinyatakan berdistribusi normal, maka langkah selanjutnya adalah melakukan uji homogenitas. Pengujian homogenitas dilakukan untuk mengetahui apakah sampel dari populasi homogen atau tidak. Uji homogenitas dilakukan berdasarkan uji kesamaan varians kedua kelas dengan menggunakan uji $\mathrm{F}$ pada taraf signifikan $(\alpha)=0,05$ dengan kriteria pengujian: jika $F_{\text {hitung }}<F_{\text {tabel }}$ maka populasi dengan varians homogen. Hasil uji homogenitas untuk data pretest dan post-test dari kelas eksperimen dan kelas kontrol dapat dilihat pada tabel 7.

Tabel 7 menunjukkan bahwa hasil uji homogenitas terhadap data post-test kelas eksperimen dan kelas kontrol adalah $F_{\text {hitung }}<F_{\text {tabel }}$ $(1,22<1,81)$ dengan varians kelas eksperimen sebesar 8,7 dan kelas kontrol 10,64.

Tabel 6. Hasil Uji Normalitas Kelas Eksperimen dan Kelas Kontrol

\begin{tabular}{|c|c|c|c|c|}
\hline \multirow{2}{*}{ Statistika } & \multicolumn{2}{|c|}{ Kelas Ekperimen } & \multicolumn{2}{c|}{ Kelas Kontrol } \\
\cline { 2 - 5 } & Pre-Test & Post-Test & Pre-Test & Post-Test \\
\hline $\mathrm{L}_{\mathrm{o}}$ & 0,1357 & 0,1181 & 0,1535 & 0,1135 \\
\hline $\mathrm{L}_{\mathrm{t}}$ & 0,1519 & 0,1519 & 0,1593 & 0,1593 \\
\hline \multirow{2}{*}{ Kesimpulan } & Berdistribusi & Berdistribusi & Berdistribusi & Berdistribusi \\
& Normal & Normal & Normal & Normal \\
\hline
\end{tabular}

Tabel 7. Hasil Uji Homogenitas Kelas Eksperimen dan Kelas Kontrol

\begin{tabular}{|c|c|c|c|c|c|}
\hline No & Data Kelas & Varians & $\mathrm{F}_{\text {hitung }}$ & $\mathrm{F}_{\text {tabel }}$ & Kesimpulan \\
\hline 1 & Pre-test kelas eksperimen & 9,25 & \multirow{2}{*}{1,34} & \multirow{2}{*}{1,81} & \multirow{2}{*}{ Homogen } \\
\hline 2 & Pre-test kelas kontrol & 12,47 & & & \\
\hline 3 & Post-test kelas eksperimen & 8,7 & \multirow{2}{*}{1,22} & \multirow{2}{*}{1,81} & \multirow{2}{*}{ Homogen } \\
\hline 4 & Post-test kelas kontrol & 10,64 & & & \\
\hline
\end{tabular}


Uji Kemampuan Awal (Uji t Dua Pihak)

Adapun hasil perhitungan uji hipotesis untuk kemampuan awal (pre-test) kelas eksperimen dan kelas kontrol dapat dilihat pada tabel 8 .

Tabel 8. Hasil Uji Hipotesis Pre-Test Siswa

\begin{tabular}{|l|c|c|c|c|}
\hline \multicolumn{1}{|c|}{ Kelas } & $\begin{array}{c}\text { Nilai } \\
\text { Rata- } \\
\text { Rata }\end{array}$ & $\mathrm{t}_{\mathrm{o}}$ & $\mathrm{t}_{\text {tabel }}$ & Kesimpulan \\
\hline Eksperimen & 49,85 & \multirow{2}{*}{1,20} & 1,999 & $\begin{array}{c}\mathrm{H}_{0} \\
\text { Diterima }\end{array}$ \\
\hline Kontrol & 46,61 & & &
\end{tabular}

Dari daftar distribusi t untuk $\alpha=0.05$ dan $\mathrm{n}=31+34=65$, maka diperoleh $\mathrm{t}_{\text {tabel }}=1,999$. Karena $\mathrm{t}_{\text {hitung }}<\mathrm{t}_{\text {tabel }}(1,20<1,999)$ dengan kriteria pengujian $\mathrm{H}_{0}: \mu 1=\mu 2$ dan $\mathrm{H}_{\mathrm{a}}: \mu 1 \neq \mu 2$, maka $\mathrm{H}_{0}$ diterima. Artinya, kemampuan awal siswa kelas eksprimen sama dengan kemampuan awal siswa pada kelas kontrol.

\section{Uji Kemampuan Akhir (Uji t Satu Pihak)}

Uji-t satu pihak digunakan untuk mengetahui perbedaan hasil belajar antara siswa kelas eksperimen yang mendapat model pembelajaran TSTS dengan siswa kelas kontrol yang mendapat model pembelajaran konvensional. Hipotesis yang diuji berbentuk $\mathrm{H}_{\mathrm{o}}: \mu_{1}=\mu_{2}$ artinya tidak ada perbedaan hasil belajar di antara kedua kelas, dan $\mathrm{H}_{\mathrm{a}}: \mu_{1} \neq \mu_{2}$ artinya ada perbedaan hasil belajar di antara kedua kelas. Hasil perhitungan uji hipotesis untuk kemampuan akhir (post-test) kelas eksperimen dan kelas kontrol dapat dilihat pada tabel 9.

Tabel 9. Hasil Uji Hipotesis Post-Test Siswa

\begin{tabular}{|c|c|c|c|c|}
\hline Kelas & $\begin{array}{c}\text { Nilai } \\
\text { Rata- } \\
\text { Rata }\end{array}$ & $t_{0}$ & $t_{\text {tabel }}$ & Kesimpulan \\
\hline Eksperimen & 80,3 & \multirow{2}{*}{7,004} & 1,670 & $\begin{array}{c}\text { Perbedaan } \\
\text { Hasil } \\
\text { Belajar } \\
\text { Signifikan }\end{array}$ \\
\hline Kontrol & 63,70 &
\end{tabular}

Dari daftar distribusi t untuk $\alpha=0.05$ dan $\mathrm{n}=31+34=65$, maka diperoleh $\mathrm{t}_{\text {tabel }}=1,670$.
Karena $\mathrm{t}_{\text {hitung }}<\mathrm{t}_{\text {tabel }}(7,004>1,670)$, maka $\mathrm{H}_{\mathrm{o}}$ ditolak dan $\mathrm{H}_{\mathrm{a}}$ diterima. Dengan kata lain, terdapat perbedaan hasil belajar di antara kelas eksperimen dan kelas kontrol. Jadi, model pembelajaran TSTS memiliki pengaruh yang signifikan terhadap hasil belajar sejarah siswa di kelas eksperimen.

Peningkatan hasil belajar sejarah siswa kelas eksperimen disebabkan oleh model pembelajaran TSTS yang menuntut cara belajar siswa aktif dengan menyelidiki dan menemukan sendiri permasalahan sejarah, serta membagi informasi yang ditemukannya kepada temanteman sekelas, karena itu hasil yang diperoleh akan bertahan lama dalam ingatan siswa dan pembelajaran menjadi tidak membosankan. Model pembelajaran TSTS memberikan kesempatan kepada siswa untuk membagikan informasi mengenai permasalah sejarah yang mereka pecahkan kepada teman-teman sekelas dengan menggunakan bahasa mereka sendiri dan pemahaman mereka terhadap permasalah tersebut. Dalam hal ini, siswa begitu aktif dan antusias untuk bekerjasama dengan teman satu kelompoknya dalam menyelidiki dan memecahkan permasalah sejarah yang diberikan oleh guru kepada setiap kelompok. Proses pembelajaran dengan menggunakan model pembelajaran TSTS membantu siswa membentuk cara kerjasama yang efektif dan saling membagi informasi, serta mendengarkan dan menggunakan ide-ide orang lain. Siswa juga menunjukan ketertarikannya untuk berdiskusi, seperti memberikan pertanyaan, pendapat dan ide-ide mengenai permasalah sejarah yang sedang dibahas. Materi pelajaran yang sedang dibahas dihubungkan dengan kehidupan sehari-hari sehingga membuat siswa tertarik untuk mempelajarinya.

Sewaktu model pembelajaran TSTS diterapkan di kelas eksperimen, peneliti menemukan beberapa kelebihan dan kekurangan dari model tersebut. Adapun kelebihan model pembelajaran TSTS yang peneliti temukan antara lain: 1) mendorong siswa melakukan kegiatan belajar sendiri dengan melibatkan kemampuan 
berpikirnya untuk memecahkan permasalahanpermasalahan sejarah melalui diskusi antarkelompok, 2) meningkatkan motivasi belajar siswa karena mereka dilibatkan secara aktif dalam proses pembelajaran, 3) siswa terlatih untuk menyampaikan ide-ide pemikirannya tentang permasalahan sejarah yang diberikan oleh guru kepada antarkelompok, 4) siswa berperan lebih dominan dalam proses pembelajaran dibandingkan dengan guru, 5) memunculkan ideide yang menarik dalam memecahkan permasalahan sejarah, 6) meningkatkan kepercayaan diri siswa hingga mampu mendorong minat belajar siswa. Sementara itu, kelemahan model pembelajaran TSTS adalah guru membutuhkan tenaga dan waktu yang lebih untuk mengelola kelas.

Hasil pengamatan selama proses pembelajaran di kelas eksperimen dan kelas kontrol menunjukkan bahwa siswa kelas eksperimen tampak lebih fokus dan lebih aktif mengikuti proses pembelajaran dibandingkan dengan siswa kelas kontrol. Siswa kelas eksperimen tergolong aktif mengikuti langkah-langkah pembelajaran dan persentase nilai rata-rata aktivitas belajarnya mencapai $91 \%$. Siswa kelas eksperimen juga lebih serius dalam menyelesaikan masalah pembelajaran, serta antusias dalam berbagi ide dan pemikiran saat berdiskusi. Sementara itu, siswa di kelas kontrol cenderung pasif dan tidak melakukan banyak kegiatan. Guru di kelas kontrol terlihat lebih aktif dengan menyampaikan materi pelajaran secara rinci kepada siswa. Siswa yang tergolong pandai di kelas kontrol seringkali merasa dirinya mampu menyelesaikan tugas sendiri, sedangkan siswa yang kurang pandai hanya menyalin pekerjaan siswa yang pandai. Hal ini membaut siswa yang kurang pandai merasa tidak percaya diri dalam menyampaikan pendapatnya.

\section{SIMPULAN}

Model pembelajaran TSTS memiliki pengaruh yang besar terhadap peningkatan aktivitas siswa dalam proses pembelajaran sejarah di kelas IPS
2 yang menjadi kelas eksperimen. Hal ini ditunjukkan dengan tingginya persentase nilai ratarata aktivitas belajar siswa kelas eksperimen yang mencapai 91\%. Model pembelajaran TSTS juga mendorong peningkatan hasil belajar sejarah siswa di kelas eksperimen, di mana nilai rata-rata post-test mereka mencapai 80,3. Nilai rata-rata ini jauh lebih tinggi dibandingkan dengan nilai rata-rata post-test kelas IPS 1 sebagai kelas kontrol yang mengikuti proses belajar mengajar dengan model pembelajaran konvensional. Nilai rata-rata post-test siswa kelas kontrol hanya 63,70 .

Hasil uji-t terhadap nilai post-test kelas eksperimen dan kelas kontrol diperoleh $t_{\text {hitung }}>$ $t_{\text {tabel }}(7,004>1,670)$. Hasil ini menunjukkan adanya perbedaan hasil belajar yang signifikan di antara kelas ekperimen dan kelas kontrol. Dengan demikian, model pembelajaran TSTS memiliki pengaruh yang besar dalam meningkatkan hasil belajar sejarah siswa kelas XI IPS 2 SMA Negeri 7 Medan.

\section{REFERENSI}

Dewijayanti, P.W., Walanda, D.K. \& Solfarina (2014). Penerapan Model Pembelajaran Kooperatif Tipe Two Stay Two Stray (Tsts) pada Pokok Bahasan Ikatan Kimia di Kelas X SMA Negeri 1 Sausu. Jurnal Akademika Kimia, 3(1), 252-257.

Hamalik, O. (2015). Perencanaan Pengajaran Berdasarkan Pendekatan Sistem. Jakarta: Bumi Aksara.

Pradhana, V.G. \& Pramukantoro, J.A. (2013). Perbedaan Model Pembelajaran Kooperatif Two Stay Two Stray (TSTS) dengan Group Investigation (GI) terhadap Hasil Belajar Siswa pada Kompetensi Menerapkan Dasar-Dasar Teknik Digital. Jurnal Pendidikan Teknik Elektro, 2(2), 661-668.

Subratha, N. (2007). Pengembangan Model Pembelajaran dan Strategi Pemecahan Masalah untuk Meningkatkan Hasil Belajar Siswa Kelas VII C SMP Negeri 1 
Sukasada. Jurnal Penelitian dan Pengembangan Pendidikan, 1(2), 135-147.

Wardhani, I.Y., Sajidan \& Maridi (2012). Penerapan Model Pembelajaran Kooperatif Tipe Two Stay Two Stray Disertai Media Audiovisual untuk Meningkatkan Kualitas Belajar Biologi Siswa Kelas XI IPA 5 SMA Negeri 7 Surakarta Tahun Ajaran 2011/2012. Jurnal Pendidikan Biologi, 4(1), 40-55.

Zulkarnain, I. \& Rachman, F. (2016). Pengaruh Pembelajaran Model Kooperatif Tipe Two Stay Two Stray terhadap Kemampuan Pemecahan Masalah Matematis dan Kemandirian Belajar Siswa Sekolah Menengah Pertama. EDU-MAT: Jurnal Pendidikan Matematika, 4(2), 31-42. http://dx.doi.org/10.20527/edumat.v4i2.25 77. 